\section{$3 \mathrm{P033}$}

\section{分子シャペロンDnaKの基質認識における構造運動 性の役割}

O田中直毅 ${ }^{1}$ 、中尾彰多 ${ }^{1} 、$ Chatellier Jean ${ }^{2} 、$ Fersht Alan R ${ }^{3}$ (1 京工繊大繊、 ${ }^{2}$ Avidis S. A.、 ${ }^{3}$ Centre for Protein Engineering, MRC Centre)

熱ショック蛋白質 HSP70 は蛋白質の生合成に㧈ける立体棈造形成や 膜透過を補助する分子シャペロンとしての機能も担っている。大晹 菌由来HSP70であるDnaK は DnaJ, GrpE, GroEL などの他の分子 シャペロンと協同して機能を発現する。これまで GroELについて構 造と機能について詳しく研究されて抢り (1)、DnaKに関しても、N 末端のATPase 部位で得たエネルギーによる C 末端の基質結合部位 の構造変化により、基貿を脱着することなどが知れれている。これま での DnaKの基質認識の研究忚結晶の立体構造情派を利用守るため にペプチドを基質モデルとする例が多いが、本研究では本来の基翼認 識機構を調べるために、変性蛋白質とDnaKの基貿結合部位フラグ メントの相互作用を電気泳動、蛍光偏光解消法によって解析した。さ らに近年蛋白質機能研究の上で運動性の重要性が䤵認識されており $(2,3)$ 、DnaKの基質認識に扔ける基質結合部位の連動性:の役淛につい て調べた。溶媒効果による基質結合部位の運動性の增減と基質親和 性の関連性を、プロテアーゼ限定分解を利用した臬動性のマッピング (2)によって明かにした。文献 (1) Tanaka, N. \& Fersht, A. R. (1999) J. Mol. Biol. 292, 173-180.(2) Tanaka, N., Ikeda, C., Kanaori, K. Hiraga, K., Konno, T. \& Kunugi, S. (2000) Biochemistry 39, 1206312068. (3) Tanaka, N., Mitani, D. \& Kunugi, S. (2001) Biochemistry $40,5914-5920$.

N.Tanaka, S.Nakao, J.Chatellier, A.R.Fersht: Role of the Conformational Flexibility on the Substrate Recognition of Molecular Chaperone DnaK

\section{$3 \mathrm{P} 035$}

\section{温度に敏感な変異型GroEL 蛋白質が示すドメイン運 動の解析}

○吉見 達成、谷口 雅昭、满端知宏、河田 承志（鳥大. 工. 生物)

GroEL C138Wは，基質タンパク質の解踓能力が温度によって異なる 特性を示すことが明らかとなっている (Kawata et al. Biochemistry, 1999）。そこで，この機能に関与する動的權造情報を得るため, ATP 拉よび GroES 結合時におけるアピカルドメインの詳細な動的構造情 報の解析がなされている GroEL R231W の性質を利用するため， 重变異体 GroEL C138W/R231Wを作製し，この機能解析を行った。 蛍光ストップトフロー解析の結果，この二重変巽体は，ATP抢占び GroES の結合に伴う動的構造変化が温度により明らかに異なる変化 を示した。また，GroEL C138Wに関して同様の測定を行ったところ 温度により異なる变化を示したが, それが二重変巽体とほぼ等しい

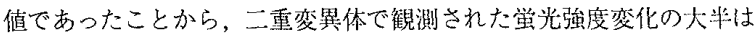
インターメディエイトドメインの動的構造変化に时来するものであ ると考元られた。そこで次に，基質タンパク質と直接的に作用する アピカルドメインの詳細な構造情報を得るため, GroEL R $231 W の$ インターメディエイトドメインに対し，C138W 変巽に代え NEM 修 飾（Martin. J.Biol.Chem, 1998）を行うことで，温度依保的特性を持 ち，尚且つアピカルドメインの動的構造情街のみの追跡が可能である GroEL R231W（NEM-RW）の作製を試みた。その結果, NEM-RW は機能面に㧍いては，ロダネーゼの解触は起こらないものの，工， ラーゼに対し温度依存的に解踓が起こる性筫を示した。さらに蛍光 ストップトフロー解析の結果，ATP 結合時のアピカルドメインの動 的構造変化が，温度によって明らかに翼なる変化として観測された。 GroEL R $231 W$ との比較により, GroELの持つ一連の陲的構造变化 とシャペロニン機能の相関関係の詳細を発表する。

T.Yoshimi, M.Taniguchi, T.Mizobata, Y.Kawata : Analysis of domain movements in a mutant GroEL displaying temperature-sensitive chaperonin function

\section{$3 \mathrm{P034}$}

ヌクレオチドによる GroELの構造変化の X 線小角散 乱法による研究

○伊野部 智由 ${ }^{1}$ 、新井 宗仁 ${ }^{1}$ 、中尾正治 ${ }^{1}$ 、侀藤 和輝 $^{2}$ 、鎆

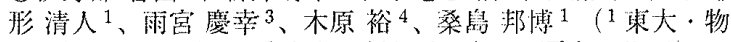
理、2 筑波大・物工、 ${ }^{3}$ 東大・新領域、 ${ }^{4}$ 関西医大·物理!

シャペロニン GroELに介助された蛋白質の效率的巻き哭りには、 ヌクレオチドによる GroELの權造変化が重要である。我々は溶液中 の虽白質の分子形状を知るのに有效な手段であるX線小角散乱法を用 いて、GroEL の棈峼変化の特徴付けを行っている。今回、淌い感度 をもつ二次元 CCD 型X線梌出器を用い、様々なヌクレオチド保在下 での GroELの構造変化を測定した結果を報告する。

GroEL の機能上重姴なATPが存在しているときの GroELの構造 特性を謂べるために、ATPを加えその加水分解币の散乱パ夕ーンを 調べた。その結果ヌクレオチド非存在下に比べ大きく散乱パターンが 変化していることが明らかとなった。このような変化は ADPや ATP y S、加水分解される CTP 存在下ではみられなかった。一方 ATP 加 水分解の中間体アナログと考えられる ADP-リン酸ナナログ（ $A_{\text {作 }}$, $\left.B e F_{x}, G a F_{x}\right)$ の䙓合体存在下では ATP と同㥞の散乱パターンの変 化を示した。これらの結果はGroEL の構造変化には少なくともATP の加水分解のエネルギーは必要でないことを示唆している。

次に、得られた散乱パターンをX線結晶構造上り訢算した散乱パ ターンと比較を行った。その結果、ヌクレオチド非存在卜の GroEL は二つのリングとも基質蛋白質と強く絬合できる状態 (close 状態)を とっているが、ATPやADP-リン酸アナログ伱在下ではGroEL-GroES 複合体の結晶中の GroEL 構造、つまり頂上ドメインが持ち、トがった 状態（open 状態）をとることが明らかになった。

更にATPによる構造変化の速度過程の測定も行ったところ、非常 に速く $\left(3 \mathrm{sec}^{-1}\right)$ 構造変化する様子が見られ、その速度はATP扣水分 解速度より10〜1000 㥉ほど速いことが明らかとなった。このことは ATPの結合により GroEL の構造転移が起こることを示している。

T. Inobe, M. Arai, M. Nakao, K. Ito, K. Kamagata, Y. Amemiya, H. Kihara and K. Kuwajima : Nucleotide-induced Structural Changes of GroEL Studied by X-ray Scattering

\section{$3 \mathrm{P} 036$}

1 分子蛍光イメージング法を用いた GroEL・GroES 結合時間と GFP folding の温度依存性の解析

○.上野太郎 ${ }^{1}$ 、田口䇦樹 ${ }^{2}$ 、多田際尚史 ${ }^{1}$ 、吉田賢不 ${ }^{2}$ 、船 津宮志 1 (1 早大·理工・物理、2 東工大・資源研)

[目的] シャペロニン GroEL は ATP存在下でGroESと結令解躈を繰 り返しながらタンバク質の折れたたみを助ける。これまでに我々は 1 分子縕光イメージング法を用いて、GroESの結合解離過程が約 3 秒. 5 秒の 2 つの反応加椿成されていること、また、GroELに䋽合した 酸変性GFPは、GroESが結合した後の3秒間は折れたたるが抑制さ れていることを明らかにしている。この結果や最近の GroEL 変異体 の研究 (Kawata Y. et al, Biochemistry, 1999) は、GroES と変性夕 ンパク質が同特にGroELに結合している新たな反地巾間体（寿命約 3 秒)が存在することを示睃している。が、1 分子倠察で得られた2 つの約 3 秒の時定数は举なる偶然の一致かもしれない。そこで、温度 を笭えて GroEL·GroESの結合時間と GFPが折れたたるを開始する までのラグ時間を測定し、雨反忘の時定数に相関があるかどうか調べ ることにした。

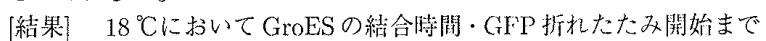

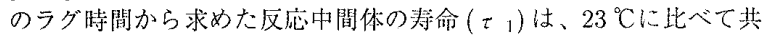
に舆くなった(下図参照)。これらの实験においてて、に同様な温度依 存性が見られたことは、反応中間体の存在をさらに確䒠にしている。 今後は、高温での反応中間体の寿命について調べる予定である。

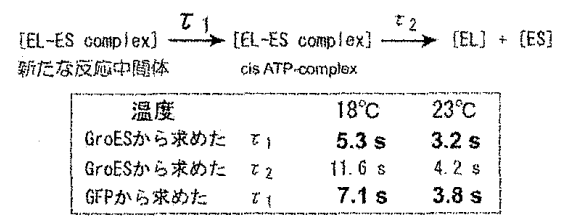

T. Ueno, H. Taguchi, H. Tadakuma, M. Yoshida, T. Funatsu : Temperature dependence of GroEL/GroES association time and GFP folding by single molecule fluorescence imaging. 